\title{
Information Support Services in Business Organizations in Kuwait
}

\author{
Abdus Sattar Chaudhry \\ Kuwait University, Kuwait
}

\begin{abstract}
Information support services in Kuwaiti businesses were reviewed focusing on access to external information sources and management of internal information. Preferences for information sources are described and approaches used to arrange access to external information are discussed. Functions and features preferred for international information systems and strategies deployed to oversee information support services are reviewed. Further investigation is desired to probe participant responses for better understanding and insights about use and exploitation of external and internal information for organizational effectiveness.
\end{abstract}

\section{Introduction}

Information is of tremendous value to business organizations in problem solving, evaluating the marketplace, developing new products and improving operational performance. Employees in businesses use information from inside as well as from outside their own organizations. Major external information sources include abstracts and indexes, bibliographies, biographical sources, databases, directories, encyclopedias and dictionaries and more. Internal information is generally a by-product of business transactions or is derived from reports prepared for regulatory submissions. Main types of internal information include employee and customer satisfaction data, purchase histories, financial and personnel information and data on marketing, purchasing, sales, manufacturing, and administration.

The systems and functions that are frequently referred to in the context of management of internal information include archives \& records management, document management, content management, enterprise portals, and websites. While there can be slight differences in these systems, in the digital operating environment the lines between them are blurred. Mostly an integrated approach to the management of digital information is more appropriate regardless of how it is produced and what form it takes.

King [1] highlights that it is important that information support service is offering what the business needs and should respond to the constantly changing demands of businesses. These services should focus on delivering value-added relevant support direct to staff who are undertaking work for clients. Jurick [2] suggests that information sources must be critically analyzed and their attributes reviewed for reliability of content and coverage. Brahem [3] asserts that internal information can provide important insights into employee and customer issues. Bono and Arnold [4] highlight that management of internal information is of vital importance for businesses. The ability to manage information effectively can help make the right decisions and achieve company objectives. Internal information helps build collective intelligence vital to the long-term development of companies.

This paper investigates approaches adopted by top Kuwaiti businesses to facilitate access to external information and to manage international information generated as a by-product of computerized transactions. The study was guided by the following research questions:

- What are the preferences of employees for different types of information sources?

- What strategies are employed by businesses to arrange access to external information?

- What functions are considered important for information support services in business organizations?

- How is the importance of information management functions perceived by businesses?

- What strategies are deployed for managing enterprise content in businesses?

- How businesses assign responsibilities for information management work?

\section{Literature Review}

Duncan [5] highlights the value and need of effective information infrastructure in companies and asserts that information managers should employ appropriate strategies to provide satisfactory information services. The role of the information specialist is more than a custodian, one in which strategic planning is required for the effective control of corporate knowledge, assessing the impact of the high cost of information access. There is a need to provide a wider range of services and develop a particular range of information skills. Smith [6] argues about the importance of considering the unique information requirements of different business niches within the small business sector. Smith explained how an information management platform overcame the challenge of providing information services to small businesses with a highly-tailored, yet cost-effective information service. 
It is imperative that information services units in companies have a good view of the needs of managers and professionals and monitor the patterns and trends prevalent in the working of those organizations. Foster [7] surveyed the support services in the corporate sector, based on in-depth interviews with leading business information managers. This study reported that business information budgets have been stable, business conditions have been turbulent but has had no real impact on the services. More information was rolled out to the clients' desktops and the services were working to add value through a variety of approaches, including evaluation and analysis, business development, and recruiting suitable information professionals. There is great interest and potential in social technology and tools and techniques Fifty-five percent of the services provide some kind of competitor information functions services support compliance functions such as `know your client'. LexisNexis takes over at the top of the expenditure league; the demand for information on Asian business markets is growing; almost all services are committed to training users in the discovery and use of digital business information sources.

Trimble [8] provides an overview about the extent and scope of information services in a company. This company relies on knowledge sharing and collaboration to maximize its value to its customers. The company created research clusters whose objective is shaping a purpose they can own. This article explains the creation of cross-center teams to support the needs of specific customers, resulting in improved service and allowing information analysts to acquire more technical knowledge about projects.

Weddell [9] noted a major shift in the provision of information services and shared practical experience and learning gained from the planning and implementation of a new information service model. The author provides evidence that, in developing a new model for information services that could be embraced by clients and staff, the company has to create a successful strategy for improving information services to support company goals. It is highlighted that the transition from traditional reference professional to the proactive role of a knowledge advisor requires adjustment to changes in information delivery. He maintained that that a number of major shifts are seen in information and records management. Now records managers are being asked to host information systems, manage digital information, preserve paper records and make sure appropriate security standards are in place. Dickinson [10] refers to Dun and Bradstreet regarding the challenges facing information professionals as they attempt to provide quality services for their users and to reduce their spending on information in response to the toughening of the business climate. Budget holders are still not convinced that spending money on quality information management is a sound investment, capable of yielding increased revenues and reduced costs. Information services are faced with the twin challenges of demonstrating the value of the company information service, and securing high quality information services support with very limited resources. Providing high quality and reliable data through user friendly interfaces and delivering new value added services in a cost effective manner remains an issue. Zeeman, Jones \& Dysart [11] identified innovative service trends in information support services in the corporate arenas. Based on detailed literature review, myriad service delivery models were reported in private sectors. The findings matched the building blocks for service models defined as E-Library, E-Services, Digitization, Physical Space, Technology, and Procurement.

Germano [12] stated that effects of national budget contraction and austerity are having a highly negative impact on information support services. While the cause of reduced funding seems rooted in budgetary pressures, the reality is that financial support is traditionally premised upon an assumption of goodwill and the benefit they provide to their clientele.

Namisango and Lubega [13] reflected on information and records management functions and pointed to a number of major shifts in this area. Information managers need to sit down with senior management in the company and information services suppliers to address emerging issues, such as the risk and impact of a data breach and steps desired to be taken.

Several guidelines for information management in organizations are available in the professional literature. Notable among these are: records management best practices guide by Mountain [14]; information management strategy by In-form Consult [15]; best practices guide in information management by Thales. [16]; theoretical framework for information management by Namisango and Lubega [17]; enterprise information management readiness in small companies by Edmunds and Morris [18]; records and information management practices among SMEs by Okello-Obura and Muzaki [19]; and corporate information management framework by Bannister [20].

\section{Data Collection}

One hundred top companies were selected from the Kuwait Stock Exchange listing based on number of employees (that was considered a valid indicator for determining the size of the company). These companies were invited to participate in the study through email. Email messages were sent to units 
that were considered relevant to information work. These included information system or center departments, corporate or business planning and development units, information technology and other similar units. They were asked to fill up an online questionnaire about information management practices in their companies. They were also requested that if some functions were not relevant to their unit, the request for provision of information may be forwarded to the relevant section. Initially, it appears pretty difficult to obtain information from business organizations but follow up phone calls and email messages helped identify relevant sections and employees to seek information about the company.

Initial data collection exercise yielded information about 27 companies. Follow up with non-respondents helped increase the number to 75 . The online questionnaire covered information support services that address two areas: access to external information and management of internal information.

\section{Findings}

Companies were requested to list their names and indicate the nature of business they are currently involved. Out of the 75 companies that participated in the first phase of the project, 16 requested that there identify is not disclosed. They thought it was necessary because of their competitiveness. The other 59 belong to seven different sectors: petroleum (16), banking and finance (15), retail trading (9) investment 6), telecommunication (5), construction and engineering (4), and real estate (4).

\subsection{Information Sources}

The first part of the questionnaire was about preference for information sources needed and used. Their preferences are listed by rank based on the mean scores.

Table 1. Preferred Information Sources $\mathrm{N}=75$

\begin{tabular}{|c|l|r|}
\hline Rank & \multicolumn{1}{|c|}{ Information Sources } & Mean \\
\hline 1 & Company \& industry reports & 4.45 \\
\hline 2 & Investment information & 3.87 \\
\hline 3 & Government sources & 3.76 \\
\hline 4 & Reference sources & 3.69 \\
\hline 5 & Books, journals, newspapers & 3.53 \\
\hline 6 & Consumer information & 3.43 \\
\hline 7 & Business sources & 3.10 \\
\hline 8 & Bibliographic databases & 3.06 \\
\hline
\end{tabular}

As expected, the most preferred source of information is company and industry reports. The other information sources preferred by the businesses are government reports and reference sources. Bibliographic databases and business information sources were reported to be the least preferred.

\subsection{Strategies for Access}

Companies were asked about their approaches for arranging access to external information. Their responses are shown in Table 2 . These are ranked by percentage of their responses. They indicated multiple choices. Therefore, the total percentage is greater than 100 .

Table 2. Arrangement for Access to Information $\mathrm{N}=75$

\begin{tabular}{|c|l|c|}
\hline Rank & \multicolumn{1}{|c|}{ Arrangement } & $\%$ \\
\hline 1 & $\begin{array}{l}\text { Links provided through } \\
\text { website }\end{array}$ & 46.67 \\
\hline 2 & $\begin{array}{l}\text { In-house library/information } \\
\text { center }\end{array}$ & 40.00 \\
\hline 3 & $\begin{array}{l}\text { Outsource to information } \\
\text { providers }\end{array}$ & 36.67 \\
\hline 4 & Subscriptions through agents & 30.00 \\
\hline 5 & $\begin{array}{l}\text { Partnership with other } \\
\text { companies }\end{array}$ & 23.33 \\
\hline 6 & $\begin{array}{l}\text { Membership in outside } \\
\text { libraries }\end{array}$ & 20.00 \\
\hline 7 & Access through aggregators & 03.33 \\
\hline
\end{tabular}

As shown in Table 2, the three main approaches used to arrange access to external information include links through websites, information centers, and outsourcing to information providers.

\subsection{Information Support Services Functions}

Companies were asked to choose functions and services that they expect from their information support services. A ranked list of their choices in provided in Table 3.

Table 3. Information Support Services $\mathrm{N}=75$

\begin{tabular}{|c|l|c|}
\hline Rank & \multicolumn{1}{|c|}{ Function/Service } & Mean \\
\hline 1 & $\begin{array}{l}\text { Compiling information on } \\
\text { competitors }\end{array}$ & 3.24 \\
\hline 2 & $\begin{array}{l}\text { Alerting service, briefs, and } \\
\text { dashboards }\end{array}$ & 3.14 \\
\hline 3 & $\begin{array}{l}\text { Adding value to social media } \\
\text { content }\end{array}$ & 3.11 \\
\hline 4 & $\begin{array}{l}\text { Arranging access to information } \\
\text { materials }\end{array}$ & 3.03 \\
\hline 5 & $\begin{array}{l}\text { Delivering information access on } \\
\text { mobile devices }\end{array}$ & 3.03 \\
\hline 6 & $\begin{array}{l}\text { Using cloud computing to store } \\
\text { information sources }\end{array}$ & 2.97 \\
\hline 7 & $\begin{array}{l}\text { Streaming media to facilitate } \\
\text { current awareness resources }\end{array}$ & 2.93 \\
\hline 8 & $\begin{array}{l}\text { Implementing search tools beyond } \\
\text { Boolean operators }\end{array}$ & 2.93 \\
\hline 9 & $\begin{array}{l}\text { Build systems to navigate outside } \\
\text { information }\end{array}$ & 2.80 \\
\hline
\end{tabular}

As shown in Table 3, most businesses prefer their information support services focus more on compiling information on competitors, preparing 
alerting briefs and adding value to social media content. Procuring information sources, delivering information on mobile devices, and using cloud computing to store information were not the preferred services in Kuwaiti businesses.

\subsection{Information Management Functions}

Businesses were requested to provide information on how they perceive about different functions or systems for managing internal information. They were requested to indicate their preferences on a scale of 1 to 5 ( 1 being the least and 5 the most important) for major functions. Mean scores were calculated from their responses. Summary of their responses, arranged in an ascending order by mean scores, is given in Table 4.

As shown in Table 1, businesses considered records management, archiving and document management as the most important functions for managing internal information. Record management focused on keeping records for long time use because of regulations of business practices while document management was being used for storage of aggregate data with ability to extract data selectively. Archiving was done for saving and keeping content for preservation. Websites, portals, and institutional repositories were perceived as less important for managing internal information. Web sites were being used for creation, review and publishing of webbased content, enterprise portals were used as online sites for a single gateway to company information and knowledge.

Table 4. Information Management Functions $\mathrm{N}=75$

\begin{tabular}{|c|l|c|c|}
\hline Rank & \multicolumn{1}{|c|}{ Function } & $\begin{array}{c}\text { Mean } \\
\text { Score }\end{array}$ & $\begin{array}{c}\text { Standard } \\
\text { Deviation }\end{array}$ \\
\hline 1 & $\begin{array}{l}\text { Records } \\
\text { management }\end{array}$ & 4.32 & 1.12 \\
\hline 2 & Archiving & 4.22 & 1.12 \\
\hline 3 & $\begin{array}{l}\text { Document } \\
\text { management }\end{array}$ & 4.20 & 1.03 \\
\hline 4 & $\begin{array}{l}\text { Content } \\
\text { management }\end{array}$ & 4.14 & 1.10 \\
\hline 5 & Web sites & 4.05 & 1.12 \\
\hline 6 & $\begin{array}{l}\text { Enterprise } \\
\text { portals }\end{array}$ & 4.04 & 1.03 \\
\hline 7 & $\begin{array}{l}\text { Institutional } \\
\text { repositories }\end{array}$ & 3.99 & 1.11 \\
\hline
\end{tabular}

Content management focused more on administration - creation and editing - of digital content.

\subsection{Information Management Strategies}

Businesses were asked about their strategies and approaches for performing the information management functions. The companies that participated in the first phase of the project belong to seven different sectors of economy. It was expected that because of the nature of business and the diversity of activities, these companies would have a great deal of variety of approaches adopted for managing information. Based on the literature review, some strategies that were reported to be used in different companies were presented in the questionnaire and participants were requested to choose those they prefer to deploy. A summary of their responses is given in Table 5 .

Table 5. Information Management Strategies $\mathrm{N}=73$

\begin{tabular}{|c|l|c|}
\hline Rank & \multicolumn{1}{|c|}{ Strategy } & $\begin{array}{l}\text { \% of } \\
\text { responses }\end{array}$ \\
\hline 1 & $\begin{array}{l}\text { Information is managed through } \\
\text { DBMS or specialized } \\
\text { applications. }\end{array}$ & 46.58 \\
\hline 2 & $\begin{array}{l}\text { An integrated system is in place } \\
\text { for access to relevant sections or } \\
\text { staff }\end{array}$ & 17.81 \\
\hline 3 & $\begin{array}{l}\text { Information is managed in } \\
\text { relevant functional units through } \\
\text { company website }\end{array}$ & 15.07 \\
\hline 4 & $\begin{array}{l}\text { An enterprise-wide content } \\
\text { management system is used }\end{array}$ & 9.58 \\
\hline 5 & Other arrangements & 10.96 \\
\hline
\end{tabular}

As shown in Table 5, a majority of businesses preferred to manage internal information in relevant units using database management systems or other specialized applications. The second preferred approach was to use an integrated system that receives information from relevant units and makes it available as and when needed to relevant sections or staff. Use of company websites and enterprise content management systems were the other preferred approaches. Some companies considered that an enterprise-wide content management system is more efficient for managing documents, records and digital assets.

Preference for database management and specialized application software for managing internal information was not reported in the previous studies, the other approaches are consistent to the strategies being used worldwide. Companies these days increasingly use web-based systems to facilitate the creation, management and delivery of information (content and documents), typically via corporate websites, portals, extranets or intranets.

\subsection{Responsibilities for Information Work}

In addition to the nature of business, size and quantum of work also varied in the businesses. Participants were asked how information management activities in their organizations are grouped or structured and who oversees the information work. Their responses are shown in Table 6. 
Table 6. Responsibilities for Information work $\mathrm{N}=66$

\begin{tabular}{|c|l|c|}
\hline Rank & \multicolumn{1}{|c|}{ Responsibility } & $\begin{array}{c}\text { \% of } \\
\text { responses }\end{array}$ \\
\hline 1 & $\begin{array}{l}\text { A senior level officer is } \\
\text { assigned to oversee } \\
\text { information work. }\end{array}$ & 45.45 \\
\hline 2 & $\begin{array}{l}\text { Responsibilities are } \\
\text { assigned to relevant } \\
\text { departments. }\end{array}$ & 22.73 \\
\hline 3 & $\begin{array}{l}\text { Information professionals } \\
\text { perform information work }\end{array}$ & 21.21 \\
\hline 4 & Other arrangements & 10.61 \\
\hline
\end{tabular}

As shown in Table 6, participants provided information on three important aspects. It was reported that in majority of businesses information management work was overseen by a senior level officer. In most companies this was assigned to the Chief Technology Officer (CTO) and only a small number of business have Chief Knowledge Officers (CKO) or Chief Information Officers (CIO). This might indicate that information management work was still perceived related to technology and there was less emphasis on the content.

The second popular approach for managing information work was assignment of these responsibilities to information professionals. These included IT specialists, records managers, archivists, content managers, and web developers. This also indicates that business organizations perceive information management more relevant to websites and other online sites.

Also, the fact that information management work was left to individual departments. It indicates that this important task is not perceived as an organization-wide responsibility, which is worth of being supervised by a senior level officer such as CIO, CKO, etc. In most businesses, Information Technology Department was responsible for information management work. This corroborates with the earlier comments that information management in most Kuwaiti business organizations is perceived predominantly as an IT function.

\section{Conclusions}

No study about information support services in Kuwaiti companies could be located from relevant professional literature. This study will help gather best practices for arranging access to external information sources and managing internal information by leading companies. The compilation of best practices will be a useful source for decision makers for formulating guidelines for information support in local and regional companies. In addition, the project report will be very good source for teaching courses related to business information.

The most preferred source of information is company and industry reports. The other information sources preferred by the businesses are government reports and reference sources. the three main approaches used to arrange access to external information include links through websites, information centers, and outsourcing to information providers. Most businesses prefer their information support services focus more on compiling information on competitors, preparing alerting briefs and adding value to social media content.

Most business organizations appear to be aware of the importance of information and need for its effective management so as to make it available to all stakeholders as and when needed. The business organizations perceive that records management and document management functions are essential for capturing, storing, organizing, and sharing internal information. They also appeared to be appreciative of the role of institutional repositories and enterprise portals in effective information management.

Business organizations prefer that information is managed in relevant departments and the need for integrated information management system is considered as a second option. Similarly, responsibilities for overseeing the information management functions by senior level officers was preferred by most organizations. Most preferred the assignment of information management function to information professionals such as IT specialists and web developers. This indicated that information management work was not considered as an organization-wide activity in most business organizations.

The questionnaire survey has provided very useful information with regard to the preferences for information sources, strategies for arranging information access, and introducing useful functions and services in information support services in companies. Further investigations are desirable to probe the answers of the company preferably using qualitative methods such as interviews and focus group discussions. This paper is based on the first phase of the study that was confined to an exploratory survey. To gain more insights into the information management strategies, it is desirable that follow-up research uses more rigor research methods such as interviews and focus group discussions. The next phase will focus on how approaches to information differed in different sectors and what was the impact of choosing a particular information management strategy on performance of businesses. A large number of responded chose to skip several questions. The follow up research will also attempt to seek answers to these questions so as to be able to understand the motivation for choosing a particular approach to manage internal information in business organizations. 


\section{Acknowledgement}

Research for this project was funded by Kuwait University project number OI01/16.

\section{References}

[1] King, E., (2011). Research and information services: Demonstrating commercial relevance. Business Information Review, 28(2) 112-118.

[2] Jurick, J. E., (2009). Access to grey literature in business: An exploration of commercial white papers. Journal of Business and Finance Librarianship, 28(2), $112-118$

[3] Brahem, A., (2013). Internal Information Sources. Available at: https://www.utwente.nl/en/bms/iebis/staff/spi 1/Incredible\%20Information\%20Strategy/3.\%20Align/14. $\% 20 \% 20-\% 20 \% 20$ Internal\%20information\%20sources/

[4] Bono, C. and Arnold, K., The evolving value of information management and the five essential attributes of the modern information professional. Financial Times Corporate. https://www.sla.org/wp-content/uploads/2014/0 3/FT-SLA-Report.pdf

[5] Duncan, M., (1997). The electronic library at work. Managing Information, 4(6), 31-34.

[6] Smith, J. (2009). An infinite number of niches. A model for delivering information services to small businesses. Business Information Review, 26(4), 273-278.

[7] Foster, A., (2008). Business information survey. Business Information Review, 25(1), 13-31.

[8] Trimble, J. S., (2010). Reflecting corporate strategy: Mitre's informaton services clusters. Information Outlook, 14(1), 22-25.

[9] Weddell, S., (2008). Transforming reference into a proactive knowledge advisory service: A case study. Reference Services Review, 36(2), 147-155.

[10] Dickinson, N., (2004). Responding to the information challenges. Business Information Review, 21(1), 92-97.

[11] Zeeman, D., Jones, R., \& Dysart, J., (2011). Assessing innovation in corporate and government libraries. Computers in Libraries, 31(5), 6-11, 13, 15.

[12] Germano, M., (2011). The library value deficit. The Bottom Line: Managing Library Finances, 24(2), 100-106.

[13] Namisango F. and Lubega T. (2014). Theoretical framework for improving information management in Small and Medium-Sized Enterprises (SMEs): The case of Uganda. International Journal of e-Education, e-Business, e-Management and e-Learning, 4(2) http://www.ijeeee.org/Papers/310-CZ603.pdf
[14] Mountain, I., (2005). Records Management Best Practices Guide. Available at: www.noplanenogain.org/..... /../fig/1255960726.pdf_copy3.pdf

[15] In-form Consult, (2005). Information Management Strategy. Available at: http://dlmforum.typepad.com/Infor mation_Management_Strategyv1.pdf

[16] Hausmann, V. S. Williams, C. H., and Schubert, P., (2014) Enterprise information management readiness: A survey of current issues, challenges and strategy, Procedia Technology, 16, 42-51.

[17] Thales, (2013). Best Practices Guide in Information Management. CHORUS - 87207345-GOV-GRP-EN-01 creation October 2013.https://www.thalesgroup.com/sites/ default/files/asset/document/best_practices_guide_in_infor mation_management_0.pdf

[18] Edmunds, A. and Morris, A., (2000). The problem of information overload in business organizations: a review of the literature. International Journal of Information Management, 20(1), 17-28.

[19] Okello-Obura, C. and Muzaki, F., (2015). An audit of records and information management practices and ICTs utilization among SMEs in Northern Uganda. Library Philosophy and Practice (e-journal), http://digitalcommons.unl.edu/cgi/viewcontent.cgi?article $=3286 \&$ context $=$ libphilprac

[20] Bannister, F., (2016). A corporate information management framework for the European Public Sector. CIMF, 2, 1-24. https://joinup.ec.europa.eu/sites/default/file s/cimf_v2.0_151116.pdf 